DOE/MC/81512-96/C0609

$$
\operatorname{CONF}-950886--8
$$

\title{
Carbonate Fuel Cell Matrix Strengthening
}

\section{Authors:}

Chao-Yi Yuh

Chao M. Haung

Richard Johnsen

\section{Contractor:}

Energy Research Corporation

3 Great Pasture Road

Danbury, Connecticut 06813

$$
\begin{gathered}
\text { RECENFO } \\
\text { DEC } 271995 \\
\text { OSTI }
\end{gathered}
$$

\section{Contract Number:}

DE-FG05-93ER81512

\section{Conference Title:}

Fuel Cells '95 Review Meeting

\section{Conference Location:}

Morgantown, West Virginia

\section{Conference Dates:}

August 9-10, 1995

\section{Conference Sponsor:}

U.S. Department of Energy, Morgantown Energy Technology Center (METC)

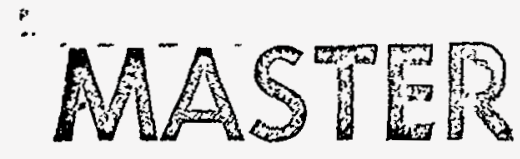




\section{DISCLAIMER}

This report was prepared as an account of work sponsored by an agency of the United States Government. Neither the United States Government nor any agency thereof, nor any of their employees, makes any warranty, express or implied, or assumes any legal liability or responsibility for the accuracy, completeness, or usefulness of any information, apparatus, product, or process disclosed, or represents that its use would not infringe privately owned rights. Reference herein to any specific commercial product, process, or service by trade name, trademark, manufacturer, or otherwise does not necessarily constitute or imply its endorsement, recommendation, or favoring by the United States Government or any agency thereof. The views and opinions of authors expressed herein do not necessarily state or reflect those of the United States Government or any agency thereof.

This report has been reproduced directly from the best available copy.

Available to DOE and DOE contractors from the Office of Scientific and Technical Information, 175 Oak Ridge Turnpike, Oak Ridge, TN 37831; prices available at (615) 576-8401.

Available to the public from the National Technical Information Service, U.S. Department of Commerce, 5285 Port Royal Road, Springfield, VA 22161; phone orders accepted at (703) 487-4650. 


\section{P5 Carbonate Fuel Cell Matrix Strengthening}

\section{CONTRACT INFORMATION}

Contract Number

Contractor
DE-FG05-93ER81512

Energy Research Corporation

3 Great Pasture Road

Danbury, CT 06813

(203)792-1460 (telephone)

(203)825-6150 (telefax)

Chao-Yi Yuh

Chao M. Huang

Richard Johnsen

Bruce Harrington

August 1994 - August 1996 (Phase II)

Schedule and Milestones

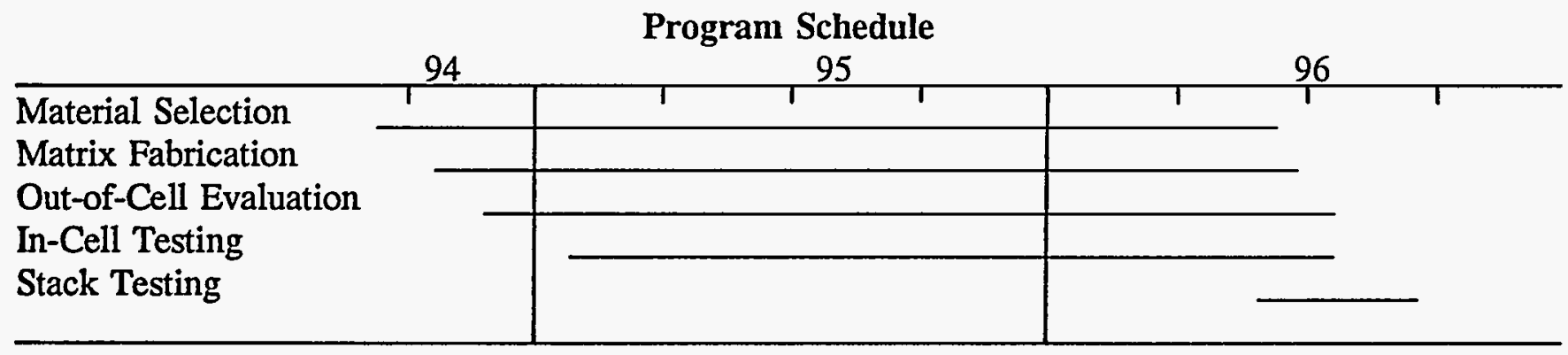

\section{OBJECTIVES}

The overall objective of this program is to improve the strength and thermal cycleability of the carbonate fuel cell matrix by reinforcing it with strong as well as stable materials.

\section{BACKGROUND INFORMATION}

The present baseline electrolyte matrix is a porous ceramic powder bed impregnated with alkali carbonate electrolyte. The matrix provides both ionic conduction and gas sealing. During fuel cell stack operation, the matrix experiences both mechanical and thermal stresses. Different mechanical characteristics of active and wet seal areas generate stress. Thermal stress is generated by nonuniform temperature distribution and thermal cycling. A carbonate fuel cell generally may experience planned and unplanned thermal 
cycles between $650^{\circ} \mathrm{C}$ and room temperature during its $40,000 \mathrm{~h}$ life. During the cycling, the electrolyte matrix expands and contracts at a different rate from other cell components. Furthermore, the change in electrolyte volume associated with freezing/melting may generate additional thermal stress. Strengthening of the matrix may be beneficial for longer-term stability of the carbonate fuel cell with respect to repeated thermal cycling.

Ceramic particulates and fibers have been used extensively for strengthening ceramic composites $(1,2)$. These types of materials have also been proposed for reinforcing carbonate fuel cell matrix (3). The choice of materials stable in carbonate is rather limited. Strong commercial ceramic fibers (e.g., $\mathrm{Al}_{2} \mathrm{O}_{3}$ ) may not have sufficient long-term (40,000 hours) stability in carbonate electrolyte. The $\gamma-\mathrm{LiAlO}_{2}$ fibers are expected to be stable in carbonate, but currently available ones are nonuniform, defective and weak in structure; their incorporation into matrices has shown no improvement in thermal cycleability in cell testing at ERC. The mechanical property requirements for the ceramic particulates are less stringent, although the incorporation of the particulates may be less effective (1). Nevertheless, the particulates are a lower cost alternative to the fibers. So far, no systematic investigation of the various materials for matrix strengthening has been carried out.

Based on the above discussion, a stable matrix strengthening scheme needs to be defined for long useful life. The effects of the strengthener shape, size and content are yet to be thoroughly investigated. Furthermore, a strengthener stable in a carbonate fuel cell may not have been identified yet. Therefore, there is a need to develop a stable matrix strengthener to optimize the strengthening schemes for further enhancing matrix strength.

\section{PROJECT DESCRIPTION}

The major efforts in this SBIR research include: 1) developing and selecting strengtheners and matrix fabrication techniques, 2) out-of-cell evaluation, 3) in-cell testing, and 4) stack testing. The technical approaches are discussed below.

Preliminary development of strengtheners and matrix casting process modifications were carried out in Phase I. The directions to develop stable strengtheners and definition of the processes for implementing the potential strengtheners were identified. A single-cell test was performed to demonstrate the benefit of the proposed strengthening scheme.

In Phase II, manufacturing of the desired strengtheners is being optimized via out-of-cell and in-cell evaluations. Screening of commercial and experimental ceramic fibers and particulates of various compositions, shapes and sizes is first carried out. The experimental strengtheners are being developed either in-house or jointly with fiber developers. The strengtheners thus screened (based on strength and stability considerations) will then be incorporated into the matrix (at different contents) for out-of-cell and in-cell evaluation. The matrix tapecasting process will be adjusted as necessary to uniformly disperse the selected strengtheners.

In the out-of-cell evaluation, the samples are filled with carbonate after binder removal. Metallography, bending and indentation testing are carried out to determine microstructure and mechanical properties. Weibull statistical analysis is conducted to determine matrix reliability. In-cell testing is primarily conducted in $250 \mathrm{~cm}^{2}$-size single cells. Gas cross-leakage through the matrix is frequently measured to determine the stability of matrix sealing efficiency during thermal 
cycling. Acoustic emission technique is used to identify test conditions which may result in matrix performance loss. Post-test analysis is performed using chemical methods, SEM/EDAX, and XRD to determine chemical stability of the strengtheners and the mechanisms of matrix strengthening.

Finally, the most promising matrix will be selected for evaluation in a 6 -cell $8,000-\mathrm{cm}^{2}$ fullarea subscale stack test. The optimized strengthening scheme will be recommended for Phase III commercialization.

\section{RESULTS}

\section{Strengthener Selection}

The considerations for material selection included strengthening potential, stability and cost. In terms of cost, expensive single-crystal whiskers or fibers were not considered. In terms of the fiber mechanical strength, the minimal strength requirement is $700 \mathrm{MPa}$, preferably higher. Porosity and nonuniformity are not acceptable for fibers because they severely degrade fiber strength. High silica content is also not acceptable because silica not only enhances the formation of weak glassy grain boundaries, but also dissolves in carbonate as silicate. $\mathrm{Al}_{2} \mathrm{O}_{3}$ and $\mathrm{ZrO}_{2}$ materials may be usable, provided that protective surface oxide layers (lithiated by $\mathrm{Li}_{2} \mathrm{CO}_{3}$ ) can form. The morphology and, hence, the protectiveness of the lithiated surface oxide is believed to be strongly affected by the microstructure of the materials. For example, preferred attack of glassy grain boundaries (generally exist in many ceramic fibers) by carbonate with subsequent strength reduction may occur during use. So far, after detailed literature survey, vendor development, and preliminary corrosion testing, several promising materials (including fibers and particulates of $\mathrm{Al}_{2} \mathrm{O}_{3}, \mathrm{ZrO}_{2}, \mathrm{LiAlO}_{2}$, etc.), experimental as well as commercial, were selected for detailed evaluation (see Table 1). Additional strengtheners will be evaluated if they become available in the future.

Table 1. Selection Status of Strengtheners: Two Fibers and Two Particulates Were Selected for Matrix Manufacturing

\begin{tabular}{|c|c|c|c|}
\hline $\begin{array}{l}\text { Strength- } \\
\text { ener }\end{array}$ & Strength & $\begin{array}{c}\text { Stability } \\
\text { (Short- } \\
\text { term) }\end{array}$ & Status \\
\hline \multicolumn{4}{|l|}{ Fiber } \\
\hline F1 & $>1.5 \mathrm{GPa}$ & Good & Selected \\
\hline F2 & $>1.5 \mathrm{GPa}$ & Fair & Selected \\
\hline F3 & & in Progress & \\
\hline F4 & & & $\begin{array}{c}\text { Under } \\
\text { Develop- } \\
\text { ment }\end{array}$ \\
\hline F5 & $<50 \mathrm{MPa}$ & & $\begin{array}{c}\text { Not } \\
\text { Selected }\end{array}$ \\
\hline F6 & $<50 \mathrm{MPa}$ & & $\begin{array}{c}\text { Not } \\
\text { Selected }\end{array}$ \\
\hline F7 & $>700 \mathrm{MPa}$ & in Progress & \\
\hline \multicolumn{4}{|l|}{ Particulate } \\
\hline P1 & Strong & Good & Selected \\
\hline $\mathrm{P} 2$ & Strong & Good & Selected \\
\hline P3 & & & $\begin{array}{c}\text { under } \\
\text { Develop- } \\
\text { ment }\end{array}$ \\
\hline
\end{tabular}

\section{Matrix Fabrication}

Matrices incorporating the selected strengtheners were then fabricated using processes modified from ERC's baseline. The process variables (viscosity, slurry formulation, doctor blade geometry, etc.) were adjusted so that a uniform dispersion of the strengthener phase while maintaining the strengtheners' aspect ration was successfully achieved. The preferred orientation of 
the fibers along the casting direction was not significant. All the fabricated green matrices had similar strength, pliability and thickness variation compared to the baseline one, adequate for cell and stack evaluation.

\section{Out-of-Cell Evaluation}

Indentation and bending tests were performed on small-size carbonate-filled matrix samples. All the tests were conducted at room temperature where the carbonate was in the solidified state. SEM analysis of the tested samples verified the strengthening mechanism as reported in the literature $(1,2)$. The results of mechanical testing are summarized in Table 2.

Table 2. Results of Mechanical Testing: Fiber Provides Most Improvements

\begin{tabular}{||c|c|c||}
\hline Strengthener & $\begin{array}{c}\text { Fracture } \\
\text { Toughness } \\
\mathrm{K}_{\mathrm{lo}} \text { MPa } \sqrt{\mathrm{m}}\end{array}$ & $\begin{array}{c}\text { Strength } \\
\mathrm{MPa}\end{array}$ \\
\hline None & 0.6 & 10 \\
\hline $\begin{array}{c}\text { Particulate P1 } \\
\text { (35wt\%) }\end{array}$ & 1.5 & 18 \\
\hline $\begin{array}{c}\text { Particulate P2 } \\
\text { (35wt\%) }\end{array}$ & 1.9 & 24 \\
\hline Fiber F1 (3wt\%) & 2.3 & 27 \\
\hline
\end{tabular}

1: from Indentation Tests

2: from Bending Tests

The fracture toughness from the indentation testing was determined by measuring how far the cracks migrate. The fiber strengthener provided the highest toughening, probably due to fiber debonding and pullout, in addition to crack deflection. Fiber debonding and pullout were observed in the post-test matrix samples. Typical bending test results are shown in Figure 1. Without the strengtheners, the matrix showed brittle failure. With the strengtheners, the tensile strength showed significant improvements, consistent with the indentation results.

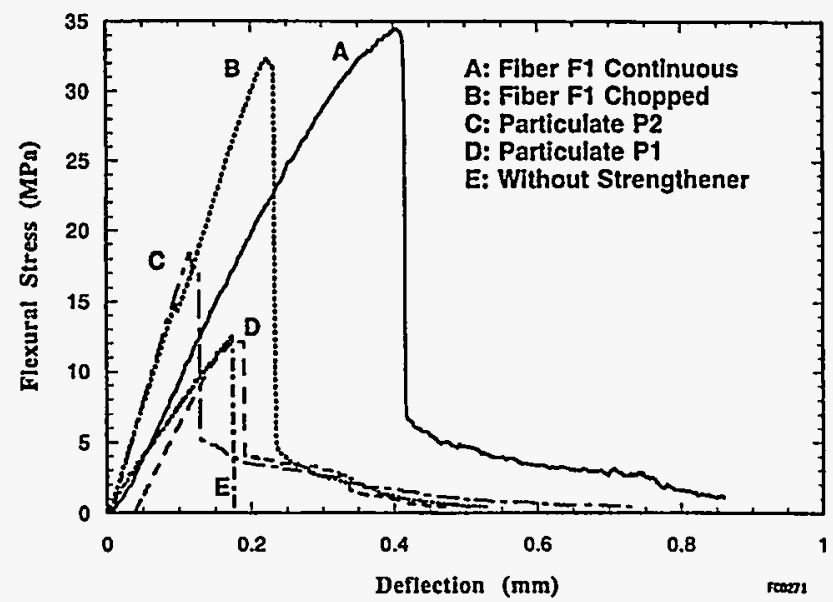

Figure 1. Matrix Bending Test Results: Fiber Showed the Highest Enhancement in Mechanical Properties

As indicated by the above results, even with only $3 \%$ fiber incorporation, the toughness and strength of the matrices have been enhanced significantly. The mechanical tests indicated that the fiber addition provided the highest strengthening effect, followed by particulates.

In terms of the particulate reinforcement, the results of Weibull statistical analysis are shown in Figure 2. The characteristic stresses (63\% probability of failure) are $8 \mathrm{MPa}$ and $20 \mathrm{MPa}$ for small and large particulate matrices, respectively. It is evident that a larger particulate size provides more strengthening. No significant difference in terms of particulate contents (>15\%) was observed, consistent with the literature information (1). Similar analysis for the fiber matrices is in progress.

Based on the out-of-cell mechanical evaluation so far, fiber is the best choice for strengthening and larger particulate is preferred. The material stability is being evaluated in longterm corrosion and cell testing. 


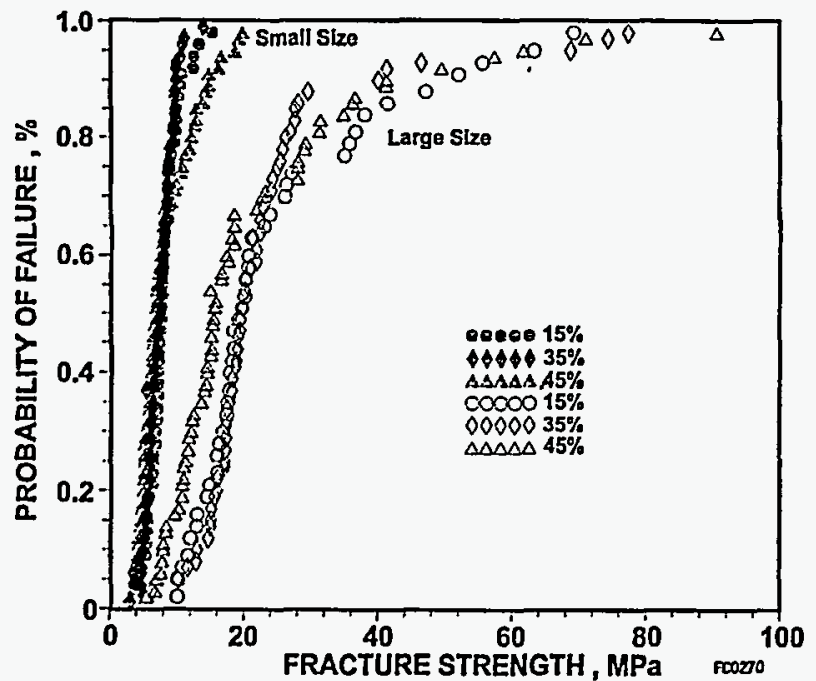

Figure 2. Weibull Analysis of

Matrices Strengthened by Particulate P2 of Two Different Sizes:

Larger Particulate Is Desired

\section{In-Cell Evaluation}

Matrices incorporating various selected reinforcements were evaluated in $250 \mathrm{~cm}^{2}$ single cells. No difficulties were encountered in implementing these advanced matrices in the baseline design. All the cells were started with ERC's standard start-up procedure. So far, about five fiber cells and five particulate cells incorporating the advanced concept were tested. The primary information recorded is the change in matrix sealing efficiency (i.e., cross-leakage) during thermal cycling. Several of these cells also had acoustic emissions recorded during thermal cycling to provide additional information for diagnosis.

The cell tests so far have shown significant improvements by the strengtheners in maintaining matrix seal efficiency during thermal cycling. The fiber strengthened matrices thermal cycled better than both the particulate ones and the present baseline, as shown in Figure 3. Post-test analysis appears to indicate that one candidate fiber (F1) used here is stable in molten carbonate after $3,000 \mathrm{~h}$ cell testing (Figure 4). More detailed analysis will be performed in the future (e.g. by TEM) to verify this observation.

Based on the cell thermal cycling results so far, the minimum required strengthener content has also been narrowed down. Higher content is desired for better strengthening. However, the cost of the added strengtheners needs to be considered for selecting the optimal content.

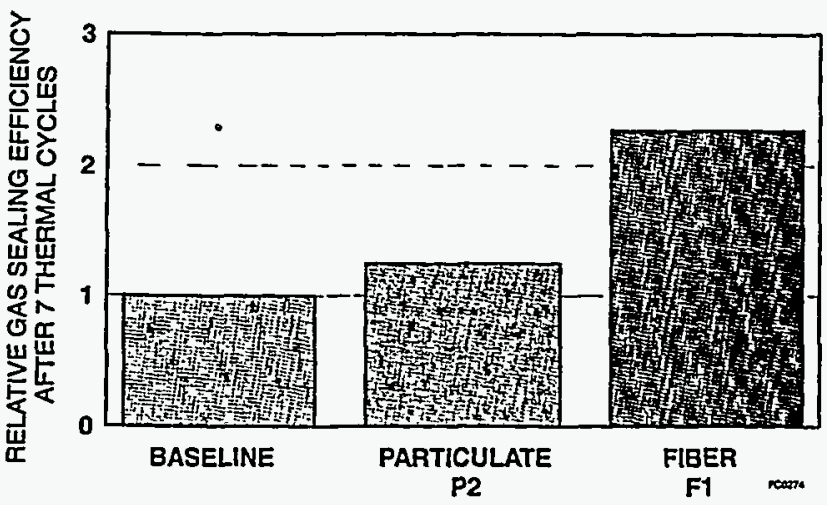

Figure 3. Cell Thermal Cycling Results: Fiber Matrix Most Effective

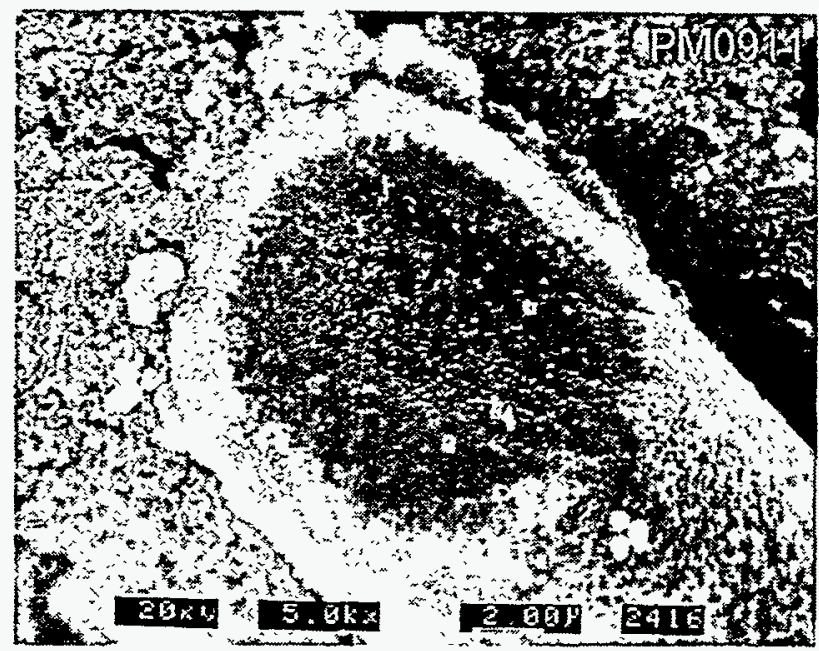

Figure 4. Post-Test Fiber (F1) Matrix (After 3,000h Cell Testing): Fiber Appears Stable 


\section{CONCLUSIONS}

- Several promising strengtheners with improved chemical and mechanical stabilities were identified. Fibers provide the highest strengthening effect, followed by particulates.

- Matrix fabrication technique was successfully modified for uniformly incorporating the advanced strengtheners, maintaining the desired aspect ratio.

- Enhanced gas sealing demonstrated using the advanced matrices.

\section{FUTURE WORK}

Based on the out-of-cell and in-cell test results available, several promising strengthening schemes were identified for further detailed evaluation. Development effort is in progress with fiber manufacturers to improve fiber quality (strength and stability). Additional candidates obtained recently will also be evaluated. More cell testing to optimize the strengthening scheme will be conducted. The matrix casting method will be simplified and scaled up for large-area manufacturing. Stack evaluation will follow.

\section{ACKNOWLEDGEMENT}

ERC would like to acknowledge the support of the U.S. Department of Energy for this SBIR effort.

\section{REFERENCES}

1. Faber, K., and Evans, A., 1983. Crack Deflection Process-I. Theory. Acta Metall., 31(4), 565.

2. Chawla, K., 1993. Ceramic Matrix Composites. Chapman \& Hall, New York.

3. Brown, P., December 1990, Physical Property Optimization of Lithium Aluminates for Fabrication of Molten Carbonate Fuel Cell Matrices, Fuel Cell News. 